Research Article

\title{
Performance of Ground Clay Brick Mortars in Simulated Chloride and Sulphate Media
}

\author{
Festus Ngui Musyimi, ${ }^{1}$ Jackson Muthengia Wachira $\mathbb{D}^{2}{ }^{2}$ Joseph Karanja Thiong'o, \\ and Joseph Mwiti Marangu $\mathbb{D D}^{3}$ \\ ${ }^{1}$ Department of Chemistry, Kenyatta University, Nairobi, Kenya \\ ${ }^{2}$ Department of Physical Sciences, University of Embu, Embu, Kenya \\ ${ }^{3}$ Department of Physical Sciences, Meru University of Science \& Technology, Meru, Kenya
}

Correspondence should be addressed to Joseph Mwiti Marangu; jmarangu2011@gmail.com

Received 13 May 2019; Accepted 31 July 2019; Published 3 November 2019

Academic Editor: Yuanxin Zhou

Copyright (c) 2019 Festus Ngui Musyimi et al. This is an open access article distributed under the Creative Commons Attribution License, which permits unrestricted use, distribution, and reproduction in any medium, provided the original work is properly cited.

\begin{abstract}
The durability of cement-based structures majorly depends on their resistivity to the aggressive media in the construction environment. The most aggressive ions commonly encountered in construction environment are chloride $\left(\mathrm{Cl}^{-}\right)$and sulphate $\left(\mathrm{SO}_{4}{ }^{2-}\right)$. The interactions of these ions with hydrated cement influence their durability and ultimate service life. This paper reports the experimental findings on an investigation on the diffusivity of $\mathrm{Cl}^{-}$and $\mathrm{SO}_{4}{ }^{2-}$ ions into mortars made from two mixtures: one made from ground calcined clay bricks (GB) and commercial ordinary Portland cement (OPC) and the other consisting of GB and Portland pozzolana cement (PPC). The test media were $3.5 \% \mathrm{Cl}^{-}$and $1.75 \% \mathrm{SO}_{4}{ }^{2-}$ solutions. For comparison, commercial OPC and PPC were also investigated. GB was blended with OPC at replacement levels of 25, 35, 45, and 50\% to make OPCGB. Similar blends were also made with PPC replacement levels of 15, 20, and 25\% to make PPCGB. Mortar prisms measuring $160 \mathrm{~mm} \times 40 \mathrm{~mm} \times 40 \mathrm{~mm}$ were cast at the water-to-cement ratios (w/c) of $0.40,0.50$, and 0.60 using each category of cement and cured in water for 3, 7, and 28 days. Compressive strength measurements were taken at each of the curing ages. The 28-day cured mortar prisms were subjected to compressive strength analysis and accelerated $\mathrm{Cl}^{-}$and $\mathrm{SO}_{4}{ }^{2-}$ ingress for 36 hours at $12 \mathrm{~V}$. Ion profiling was done on the mortars, and diffusion coefficients of the $\mathrm{Cl}^{-}$and $\mathrm{SO}_{4}{ }^{2-}$ ions were approximated. The results showed that there was an increase in compressive strength after exposure to $\mathrm{Cl}^{-}$and $\mathrm{SO}_{4}{ }^{2-}$ ions. In addition, the ingress of $\mathrm{Cl}^{-}$and $\mathrm{SO}_{4}{ }^{2-}$ ions decreased with an increase in depth of cover. Blended cement exhibited lower $\mathrm{Cl}^{-}$and $\mathrm{SO}_{4}{ }^{2-}$ ingress than OPC. The ingress of $\mathrm{Cl}^{-}$was observed to be higher than that of $\mathrm{SO}_{4}{ }^{2-}$ ions. The ingress of $\mathrm{Cl}^{-}$and $\mathrm{SO}_{4}{ }^{2-}$ ions increased with an increase in w/c ratio. The results further showed that there was a drop in the ingress of $\mathrm{Cl}^{-}$and $\mathrm{SO}_{4}{ }^{2-}$ ions with an increase in replacement up to 35 percent for OPC. A 15 percent replacement showed a better compressive strength development compared with 20 and 25 percent replacement for PPC. Blended cement showed lower apparent diffusion coefficients $\left(D_{\text {app }}\right)$ compared with OPC. PPC, OPCGB-35,

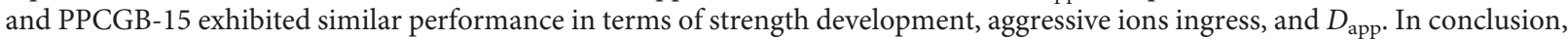
it was found that the test cements, PPCGB-15 and OPCGB-35, can be used in similar tested environments as commercial PPC.
\end{abstract}

\section{Introduction}

The need for housing and general infrastructure has resulted in increased demand for cement globally. Ordinary Portland cement (OPC) has been in use for many decades. However, $\mathrm{OPC}$ is an expensive binder due to the fact that its production is associated with the high energy demand for its manufacturing process [1]. The high cost is attributed to the fact that during OPC production, calcareous and argillaceous materials are calcined in a rotary furnace at a temperature in excess of $1300^{\circ} \mathrm{C}$ [1]. This makes OPC an unaffordable product in many developing countries. The OPC production process involves significant environmental damage with respect to carbon dioxide production and raw material requisition $[2,3]$. Cement manufacturing releases carbon dioxide in the atmosphere when calcium carbonate is 
heated [3]. The gas is also emitted when petroleum-based fuel is burnt in the kiln during the clinkerisation process. The cement industry is the second largest carbon dioxideemitting industry behind power generation. Carbon dioxide is considered as the main greenhouse gas causing global warming and climate change in the world [4].

There is a growing need to lower the cost of production of cement and reduce the amount of carbon dioxide emission in cement industries. Therefore, continuous attempts have been made to reduce the cost of production of cement. One of the ways involves the shift from use of wet to dry process of clinkerisation to lower the high energy requirements. Secondly, cement industries have adopted the use of natural pozzolana which mainly requires grinding and is thus less costly in terms of preparation to make blended cement. However, the availability of natural pozzolana such as volcanic ash in Kenya is limited compared with clays $[5,6]$.

In the Kibwezi region in Kenya, building materials are unaffordable to a majority of its low earning population. This has led to poor housing and structures. Calcined clay has been shown to be potential pozzolanic materials. Calcined clay in the form of ground fired bricks has been used in improving the properties of lime mortars. It has been established that most clays in Kenya are pozzolanic when calcined. Ground broken bricks (GB) can thus be put to an economic use by blending it with OPC and Portland pozzolana cement (PPC). The addition of pozzolana reduces the quantity of clinker used, hence making the cements affordable. This has the potential to lower the cost of construction, hence improving the living standards of the lowincome earners. However, the test cements are subject to being degraded by aggressive agents when used in day-today construction. These aggressive agents may include sulphates, chlorides, moisture, and carbon (IV) oxide [7]. The steel rebar corrosion of the reinforced concrete (RC) caused by the ingress of chloride ions is the most severe problem affecting the durability of concrete constructions, especially in saline environments [8]. Sulphate attack is considered a major deteriorative problem occurring when the cement based materials, such as concrete, mortars, and buildings are exposed to the sulphate ions environment. Wastewater with high concentrations of sulphates is not treated especially in tannery, but discharged directly into the integrated wastewater [2]. These ions may be carried into inner sections of concrete by ionic diffusion, capillary absorption, permeation, and convective flow through the pore system among others [7]. Ordinary Portland cement, (OPC) is prone to attack by aggressive media. The use of OPC has continued regardless. Potential pozzolanic clays require assessment in terms of strength and durability in aggressive media. The present study therefore aimed to investigate the durability of the resultant test cement in sulphate- and chloride-rich environments. In the study, the Kibwezi-based ground calcined clay bricks were used in partial replacement of OPC and PPC at varying proportions to make blended cement. Mortar prisms made from the cements were subjected to simulated aggressive media made of sulphate and chlorides. An accelerated ingress technique was used to subject them to the solution. Diffusivity and diffusion coefficients of ingressed sulphate and chloride ions were evaluated.

\section{Materials and Methods}

2.1. Materials. Broken bricks were obtained from Mbuinzau in Kibwezi region that lies between longitudes $37^{\circ} 40^{\prime}$ and $38^{\circ}$ $20^{\prime} \mathrm{E}$ and latitudes $2^{\circ} 7^{\prime}$ and $3^{\circ} 16^{\prime} \mathrm{S}$ in Kenya. Small pieces of waste broken bricks with brown colour presumed to be well fired were picked from different kilns. In each kiln, six samples weighing approximately $3 \mathrm{~kg}$ were collected and then packed in polythene bags. For control purposes, commercial pozzolana was sourced from Ngurunga quarry, Athi River, Machakos County. This is a source of pozzolana for most cement manufacturers in Kenya. The OPC and PPC were obtained from the appointed distributor in Thika town, while sand was obtained from commercial distributors at Ruiru. Table 1 shows the XRFS analysis chemical composition in terms of oxides of sampled ground broken clay bricks (GB), OPC and PPC.

The packed broken bricks from each region were crushed into smaller pieces using a HFM 100 grinder model $62 \mathrm{~B} / 140$, HG Herzog (1980). The resultant clay samples were dried at $110^{\circ} \mathrm{C}$ in an oven to constant weight. They were then cooled and finely ground using a laboratory ball mill $62 \mathrm{~B} / 140$, HG Herzog (1980) to $90 \mu \mathrm{m}$ mesh size. The particle size distribution of calcined clay bricks was determined using the laser granulometry method. A range of measurements between 0.90 and 175 microns were used. The powdered GB was blended with commercial OPC to replacement levels of 25,35 , 45 , and 50 percent replacement. The GB was similarly blended with commercial PPC at 15, 20, and 25 percent replacement. The blended samples were then milled using the laboratory ball mill for ten minutes to ensure uniformity and complete mixing. They were labeled appropriately as OPCGB-25, 35, 45 , and 50 percent replacement levels as well as PPCGB-15, 20 , and 25 percent replacement levels. Sand as obtained from the sampling site was put in a $0.05 \mathrm{~mm}$ sieve tray, washed by spraying with tap water, and sun-dried to a constant weight. The dry sand was sieved using a $5 \mathrm{~mm}$ sieve and mixed thoroughly. Laboratory solutions of chlorides and sulphates were made by dissolving requisite amount of anhydrous sodium chloride and sodium sulphate salts in water (in a separate volumetric flask). The solutions were diluted to a concentration of $3.5 \%$ for both $\mathrm{NaCl}$ and $\mathrm{Na}_{2} \mathrm{SO}_{4}$. They were labeled "Cl" and "SO," respectively, and $0.3 \mathrm{M}$ sodium hydroxide solution was also prepared and labeled accordingly.

\subsection{Methods}

2.2.1. Preparation of Mortar Prisms. Preparation of mortar prisms were done in accordance with the East African Standard (2000) with slight modifications. Three mortar prisms each having dimensions of $160 \mathrm{~mm} \times 40 \mathrm{~mm} \times 40 \mathrm{~mm}$ were prepared simultaneously. This was done by mixing $450 \mathrm{~g}$ of the test cement and $1350 \mathrm{~g}$ of the graded sand with a trowel on a nonporous plate for one minute. Requisite amount of water was added to the mix to make a workable paste into a 
TABLE 1: Average chemical composition of the sampled broken bricks, OPC, and PPC.

\begin{tabular}{lccc}
\hline \multirow{2}{*}{ Oxides } & \multicolumn{3}{c}{ Percentage composition (\%) } \\
& Broken bricks & OPC & PPC \\
\hline $\mathrm{SiO}_{2}$ & 64.55 & 29.53 & 28.99 \\
$\mathrm{Al}_{2} \mathrm{O}_{3}$ & 13.66 & 5.99 & 6.54 \\
$\mathrm{CaO}$ & 2.12 & 62.67 & 44.76 \\
$\mathrm{Fe}_{2} \mathrm{O}_{3}$ & 4.68 & 3.43 & 3.35 \\
$\mathrm{MgO}$ & 0.39 & 1.45 & 2.22 \\
$\mathrm{Na}_{2} \mathrm{O}$ & 2.13 & 0.27 & 0.73 \\
$\mathrm{~K}_{2} \mathrm{O}$ & 0.87 & 0.60 & 0.66 \\
\hline $\mathrm{SiO}_{2}+\mathrm{Al}_{2} \mathrm{O}_{3}+\mathrm{Fe}_{2} \mathrm{O}_{3}$ & 82.89 & - & - \\
\hline
\end{tabular}

stainless steel bowl. Then, mixing was continued using a trowel for further four minutes to produce a cement mortar of homogeneous consistency. During the mixing process, care was taken to ensure that little or none of the materials was lost. The mixture was then put into a grease-lubricated three-pong mould of dimensions $40 \mathrm{~mm} \times 40 \mathrm{~mm} \times 160 \mathrm{~mm}$. The assembled mould was placed on the vibrating machine and then firmly held in position by means of a suitable clamp. Filling of the prepared cement mortar was done using a suitable hopper. Compaction of the mortar was done by vibration for two minutes at $12000 \pm 450$ vibrations per minutes. The above procedure was repeated with PPC, OPCGB, and PPCGB producing prisms in triplicate for each category of cement. Immediately after vibration, the mortar prisms were removed and labeled for identification (date cast/cement type) as OPCGB-25, 35, 45, and 50 as well as PPCGB-15, 20, and 25. This was indicating the replacement levels of both OPC and PPC with the GB. The prisms were stored under water in a temperature-controlled room maintained at a temperature of $21 \pm 2^{\circ} \mathrm{C}$ and relative humidity above 90 percent for 24 hours \pm 30 minutes. The prisms were covered with a flat impervious sheet of polythene paper in the curing room maintained at $21 \pm 2^{\circ} \mathrm{C}$. After 24 hours, the prisms were demoulded as shown in Figure 1.

The marked prisms were immediately submerged in water, and a batch of all prism categories were cured for 3, 7, and 28 days in accordance with Kenya Standard KS EAS 18 : 2008 curing conditions.

The compressive strength analysis was done in accordance with KS EAS 18-1: 2008 specifications. At the age of 3, 7 , and 28 days, for each cement category, three prisms were removed from the deionized water and allowed to drain in a nonabsorbent surface. The specimens were removed and broken into two halves using a concrete cutter (1980) (number 19547). Each half was used instead of the $50 \mathrm{~mm}$ mortar cubes prescribed in the standard due to their availability to test for compressive strength. This was done by using a compressive strength machine (model number SSC546) following the instructions on the instrument manual.

2.2.2. Sulphate and Chloride Ingress. For each category of cement, three prisms, cured for twenty eight days, were subjected to chloride profiling using a method prescribed by ASTM C1202-97 (2001). The cathode compartment of an electrochemical set up was filled with $500 \mathrm{~cm}^{3}$ of 1.75 percent sodium sulphate solution. The anode compartment cell was filled with $500 \mathrm{~cm}^{3}$ of $0.3 \mathrm{M} \mathrm{NaOH}$ solution. The same procedure was repeated with 3.5 percent of $\mathrm{NaCl}$ in the cathode compartment.

For each cement category, a mortar prism was put into the assembled test cell using epoxy coating. Stainless steel electrodes were mounted on the cells and fastened with a clamp at both ends to hold the whole assembly together. An external voltage cell was used to give a potential difference of $12 \pm 0 . \mathrm{IV}$ between the electrodes. The power was switched on with the electric current in the test cell being monitored by use of a digital ammeter at intervals of thirty minutes for a period of thirty-six hours. The top of each compartment was covered with a polyethylene paper to minimize evaporation of the solutions. Both solutions in the anode and cathode compartments were stirred periodically by use of a glass rod to maintain a relatively uniform concentration throughout the compartment depth.

After exposure duration was over, the mortar prisms were removed from the set up. The epoxy coating was removed from the outer portion of the mortar prisms. The mortar prism surfaces that were previously in contact with solution containing the aggressive ions and epoxy coating were thoroughly polished using sand paper. Then, they were sealed in plastic bags at both ends ready for profiling.

Using a water-lubricated saw of $2 \mathrm{~mm}$ thick, each prism was sliced into one-centimeter thick layers at different depths. The core of each sliced prism was drilled using a diamond drill bit. The samples were dried in an oven at $105^{\circ} \mathrm{C}$ for 24 hours. The dried samples were pulverized to obtain particles size of less than $76 \mu \mathrm{m}$ in a pulverizer. After pulverization, the samples were appropriately packed in clean plastic bags and labeled with respect to the distance of exposure from aggressive media for each prism for chloride and sulphate analysis.

(1) Analysis of Sulphate Ions. $1 \mathrm{~g}$ of the finely ground cement mortar was weighed and placed in a clean $100 \mathrm{ml}$ plastic beaker. $50 \mathrm{ml}$ of distilled water was added and then shaken for about 10 minutes in a reciprocal shaker. The mixture was slowly filtered using Whatman filter paper number $42.10 \mathrm{ml}$ of the filtrate was transferred in to clean beaker, and $5 \mathrm{ml}$ of $0.05 \mathrm{M} \mathrm{HCl}$ was added and diluted to $500 \mathrm{ml}$.

The solution was heated to boiling point, and $20 \mathrm{ml}$ of 5 percent barium chloride solution was pipetted dropwise with constant stirring. The contents were kept simmering for half an hour for complete precipitation and then filtered through Whatman filter paper number. 42. The residue was washed with hot water to remove all soluble chloride ions. Then, the residue was put in a crucible whose mass was known. This was ignited and reweighed, and its mass was recorded. The mass of barium sulphate was obtained by subtracting the mass of crucible from the mass of crucible and residue. The mass of sulphate ions was therefore evaluated from this result.

(2) Chloride Analysis. $10 \mathrm{~g}$ of the ground samples was accurately weighed into a $200 \mathrm{ml}$ plastic bottle. $75 \mathrm{ml}$ of 


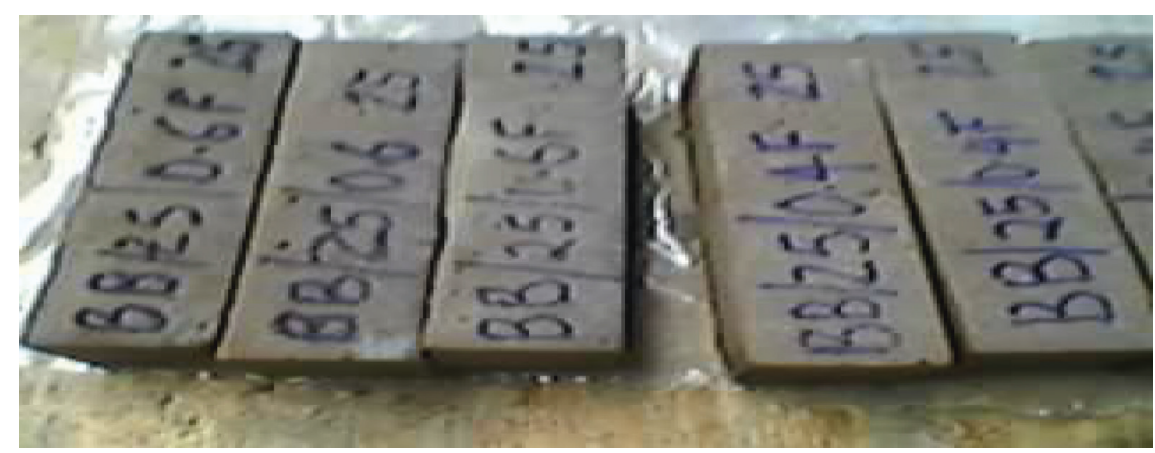

FIgURE 1: Freshly cast and marked mortar prisms.

deionized water was then added and shaken in a reciprocal shaker machine for an hour. The sample was left to settle for 30 minutes. $25 \mathrm{ml}$ concentrated nitric acid was added sequentially while stirring with a glass rod to break lumps of cement formed after addition of deionized water. The mixture was stirred for 15 seconds with a glass rod, which was then rinsed into the beaker using water. The contents in the glass beaker were allowed to stand for 4 minutes. The resultant solution was then placed on a preheated hot plate until it just boiled. It was then cooled and vacuum filtered using a Buchner funnel with a medium grade prerinsed filter paper. The residue was rinsed twice with water. The filtrate was transferred to a $100 \mathrm{ml}$ volumetric flask. $0.1 \mathrm{M}$ sodium hydrogen carbonate solution was added to the filtrate dropwise with stirring until effervescence ceased. The resultant solution was then made up to $100 \mathrm{ml}$ in a volumetric flask. Three portions containing $20 \mathrm{ml}$ pipette volumes each were sequentially taken from the volumetric flask and transferred into three separate $250 \mathrm{ml}$ conical flasks. $2 \mathrm{ml}$ of 5 percent potassium chromate indicator was added to each $250 \mathrm{ml}$ conical flask. Titration was done using $0.1 \mathrm{M}$ silver nitrate in triplicates. A blank titration was determined following a similar titration procedure. The concentration of the chloride ions in the sample was calculated using the following equation:

$$
\mathrm{Cl}^{-}=\frac{\left\{\left(V_{1}-V_{2}\right) \times 35.46 \times M\right\}}{V},
$$

where $V_{1}$ final volume of the extract, $V_{2}$ is the volume of the blank, $V$ is the volume of silver nitrate, and $M$ is the molarity of silver nitrate used.

\section{Results and Discussions}

3.1. Compressive Strength. The results for the compressive strength of the mortars are presented in Figures 2-4.

It was observed that w/c ratio greatly influenced the ultimate strength of all test cement mortars in all the days of curing. The compressive strength decreased with an increase in $w / c$ as $0.4>0.5>0.6$ for all the days. This could be attributed to increased porosity at high $\mathrm{w} / \mathrm{c}$. The $\mathrm{w} / \mathrm{c}$ ratio is considered as the most important factor affecting mortar/ concrete strength. This is because it affects the porosity of the hardened paste. The flow of the mixture as well as the cohesion between paste and aggregate is also affected by the quantity of water. As a result, it influences the overall strength of mortar $[5,9]$.

Generally, OPC exhibited higher compressive strength than all pozzolana cements. It is expected for pozzolanic cements to exhibit a slow compressive strength development on the early days compared with OPC. This could be attributed to the slow strength development of the incorporated pozzolana in PPC. The OPC contains a higher proportion of $\mathrm{C}_{3} \mathrm{~S}$ that is mainly responsible for the strength of the cement [5]. Approximately, half of $\mathrm{C}_{3} \mathrm{~S}$ present in typical cement will be hydrated by 3 days and 80 percent by 28 days. The hydration of $\mathrm{C}_{2} \mathrm{~S}$ in pozzolana cement does not normally proceed to a significant extent until approximately after 14 days, which delays the release of heat of hydration and thus increases its strength at later days. $\mathrm{C}_{3} \mathrm{~S}$ phase sets quickly making the OPC exhibit a higher compressive strength than pozzolana cements by the $28^{\text {th }}$ day. However, over time, PPC would be expected to attain higher compressive strength even higher than OPC due to pozzolanic reaction which continues after the $28^{\text {th }}$ day. By the $28^{\text {th }}$ day, OPC hydration reactions are expected to be complete.

The compressive strength was observed to increase with curing age for all cement categories in this study. This is linked to the fact that the hydration reaction of cement mixes which is responsible for the hardening takes place slowly. The hydration reaction was continuously taking place and hence the strength development. From Figure 3, it is clear that the $7^{\text {th }}$ day compressive strength of all the pozzolana cement was higher than the minimum Kenyan standard requirements except OPCGB-50.

The compressive strengths of PPCGB-15 and PPCGB-20 were above OPCGB-50 in all curing days. These are expected to be similar blends as commercial PPC which is about 35 percent of the pozzolana blend (KEBS, 2001). Similarly, from Figure 4 , the compressive strength of PPCGB-15 at the $28^{\text {th }}$ day is in fact slightly higher than that of the commercial PPC. The used test commercial PPC, in this case, could have been prepared using an amount of pozzolana closer to the minimum requirement. In the manufacture of commercial PPC, the Kenyan standard recommends a range of 25-35 percent pozzolana material addition to the clinker (KEBS, 2001). The compressive strength of OPCGB-35 is similar to PPC on the $28^{\text {th }}$ day as expected. Both blends have met the Kenyan standard. The Kenyan standard, KS EAS 168-1 (2008), requires that PPC has a minimum strength of 


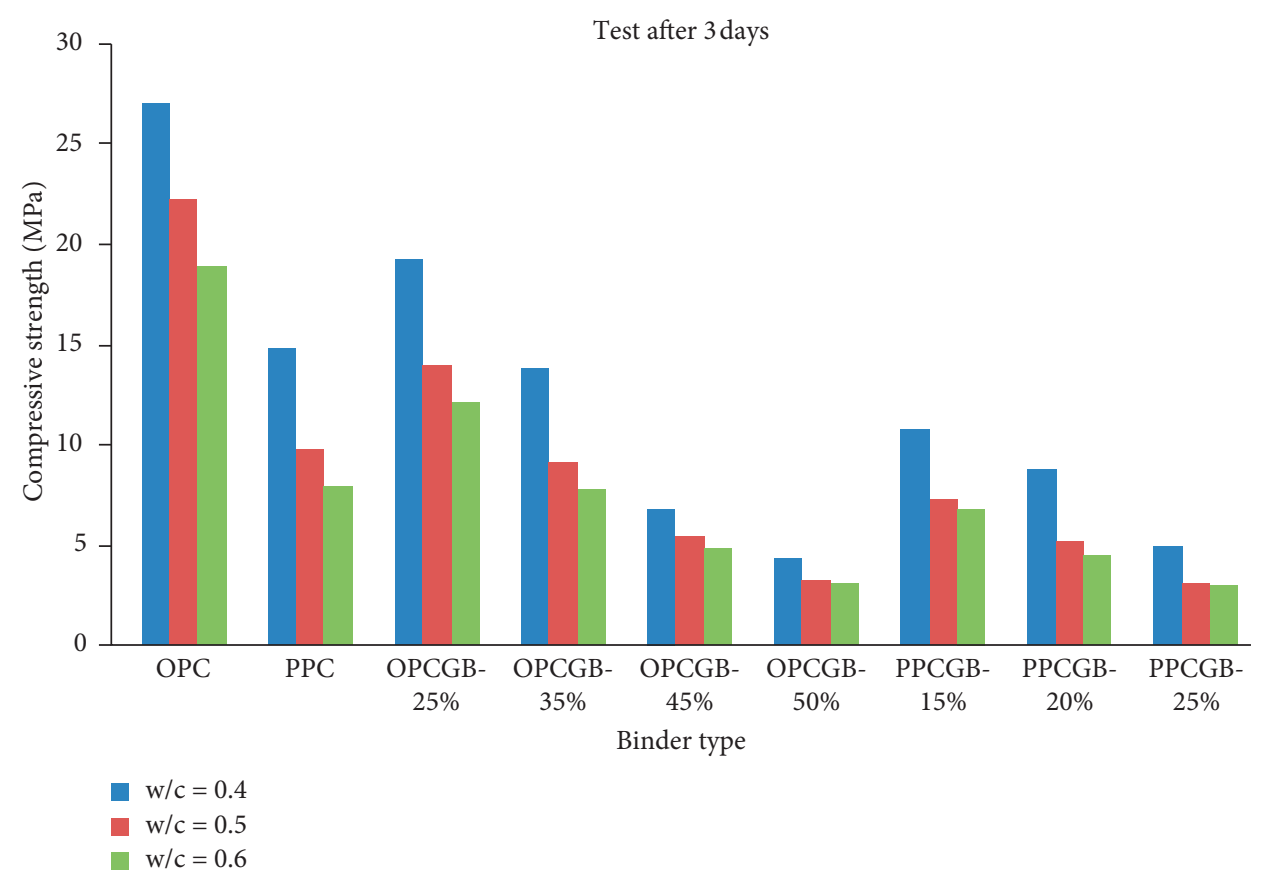

Figure 2: Compressive strength of test cements after 3 days of curing.

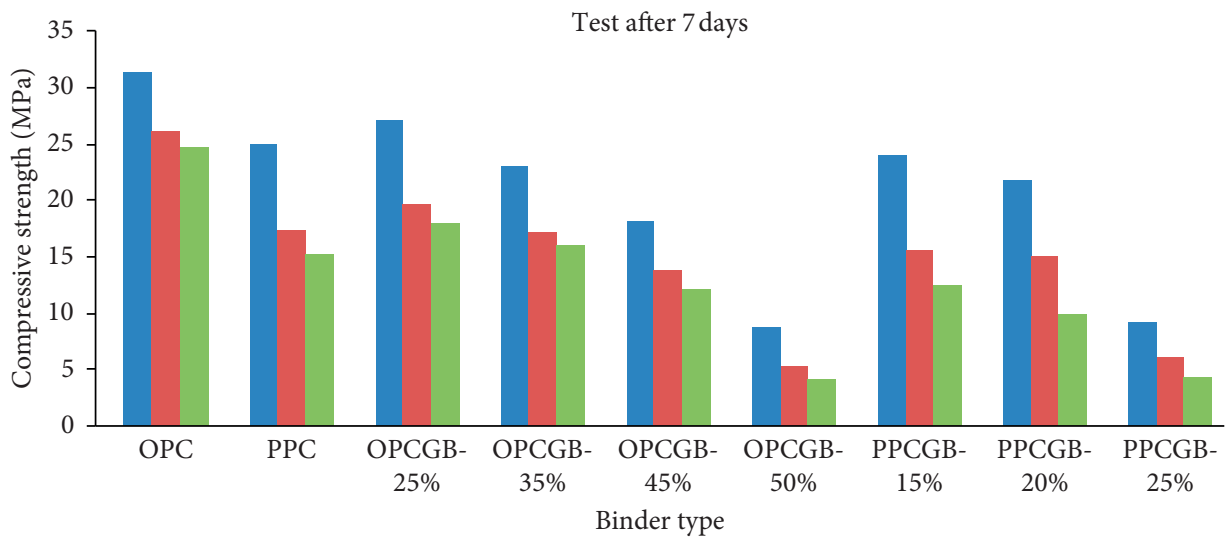

$\mathrm{w} / \mathrm{c}=0.4$
$\mathrm{w} / \mathrm{c}=0.5$
$\mathrm{w} / \mathrm{c}=0.6$

Figure 3: Compressive strength of test cements mortar after 7 days of curing.

$15 \mathrm{MPa}$ at the $7^{\text {th }}$ day of curing while at the $28^{\text {th }}$ day be at $32.5 \mathrm{MPa}$. OPC should have a minimum of $25 \mathrm{MPa}$ at the $7^{\text {th }}$ day while at the $28^{\text {th }}$ day it should have a minimum of 42.5 MPa (KS 02-1262, 1963).

In this study, there is a considerable decrease of compressive strength with an increase in partial replacement of GB with both OPC and PPC on $3^{\text {rd }}$ and $7^{\text {th }}$ days. A similar behaviour is also seen with an increase in partial replacement of GB with PPC on the $28^{\text {th }}$ day. This is also the case with OPC after 35 percent replacement on the $28^{\text {th }}$ day. This could be as a result of availability of more unreacted pozzolana. This provides less resistance to stress as the nonbonded particles increase, hence decreasing compressive strength development.

There was no significant difference in terms of compressive strength gain between OPCGB-35 and commercial PPC for $3^{\text {rd }}, 7^{\text {th }}$, and $28^{\text {th }}$ days at $\mathrm{w} / \mathrm{c}=0.40, \mathrm{w} /$ $\mathrm{c}=0.50$, and $\mathrm{w} / \mathrm{c}=0.60$, respectively. The $\mathrm{T}$-calculated values were $0.1020,0.5423$, and $0.9196 ; 0.2203,0.5352$, and 0.4419 ; and $0.0924,0.1000$, and 0.0769 for $3^{\text {rd }}, 7^{\text {th }}$, and $28^{\text {th }}$ days, respectively. This could be linked to the fact that commercial PPC is about 35 percent of the pozzolana blend. The results also showed no significant difference between PPCGB-15 and commercial PPC for $3^{\text {rd }}, 7^{\text {th }}$, and 


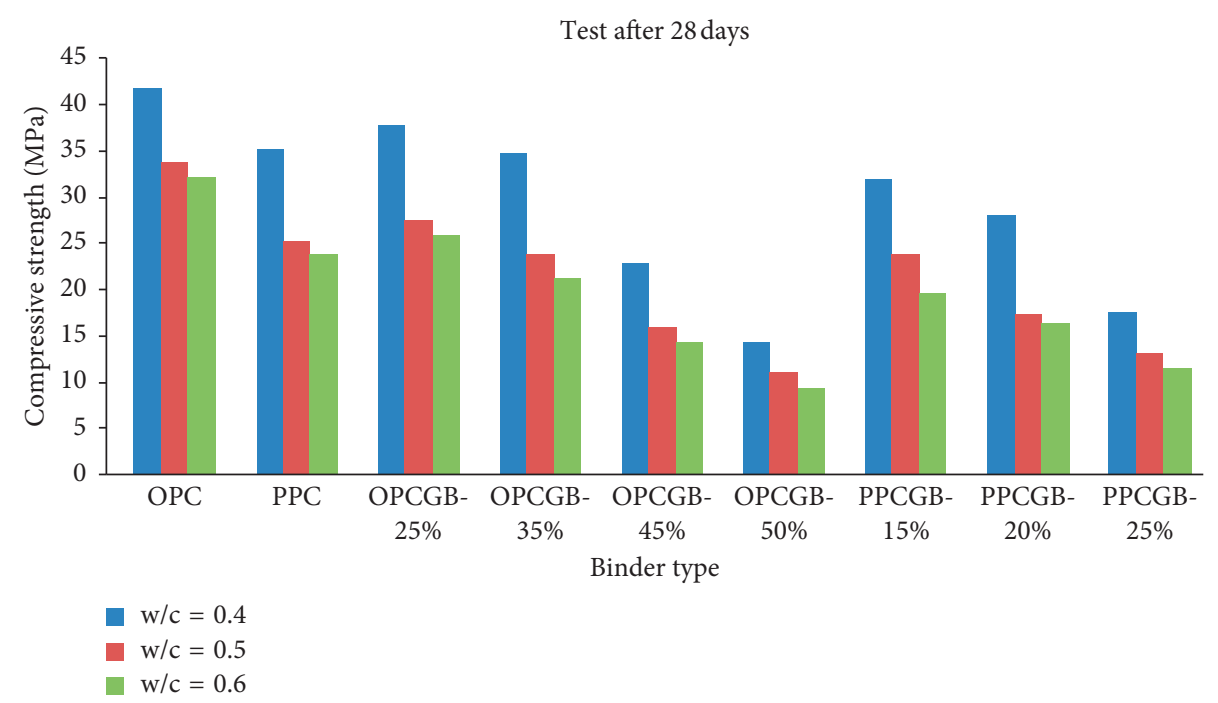

FIgURE 4: Compressive strength of test cements mortar after 28 days of curing.

$28^{\text {th }}$ days at $\mathrm{w} / \mathrm{c}=0.40, \mathrm{w} / \mathrm{c}=0.50$, and $\mathrm{w} / \mathrm{c}=0.60$, respectively. The $\mathrm{T}$-calculated values were $0.0138,0.0059$, and $0.3384 ; 0.4857,0.1439$, and 0.2183 ; and $0.0856,0.1103$, and 0.0039 for $3^{\text {rd }}, 7^{\text {th }}$, and $28^{\text {th }}$ days, respectively. The $\mathrm{T}$-calculated values were also way below the $T$-critical value of 6.314 .

The minimum standard requirements of compressive strength for cement mortar prisms by EAS 148-1(2000) specify a 7 and 28 days compressive strength of 16.0 and $32.5 \mathrm{MPa}$, respectively, for Portland pozzolana cements. Both OPCGB-35 and PPCGB-15 cement met this specification on the $28^{\text {th }}$ day regardless of the w/c used. The rest of the test pozzolana cement did not meet the standards though it can be used for light masonry construction purposes like brick binders (ASTM C 91). For general masonry construction, a compressive strength of $3.5 \mathrm{MPa}$ at 7 days and $9 \mathrm{MPa}$ at 28 days is recommended (ASTM C 91). ASTM C 150 specifies for structural quality material with a compressive strength of $12.6 \mathrm{MPa}$ at 3 days and 19.6 $\mathrm{MPa}$ at 7 days.

3.2. Sulphate and Chloride Profiling. Figures 5-10 show the sulphate and chloride profiles against depth of cover of each category of the mortar cubes. These involved the determination of the concentration of the sulphate and chloride ions $\left(\times 10^{-10} \mathrm{~g} / \mathrm{g}\right)$ at different depths of cement mortar bulk of the test cements.

From the profiles, there is a sharp decrease in the sulphate and chloride concentration in all categories of cements at the shallow depths of cover of less than $2 \mathrm{~cm}$. This could be linked to nearness of the exposed surface to the aggressive media. All cements bind a proportion of the aggressive ions present. Binding process reduces diffusion rates of the ions into the cement bulk of the cement involved. Binding of $\mathrm{Cl}^{-}$ ions is as a result of formation of Friedel's salt (3CaO. $\mathrm{Al}_{2} \mathrm{O}_{3} \cdot \mathrm{CaCl}_{2} \cdot 10 \mathrm{H}_{2} \mathrm{O}$ ) through the reaction shown in the following equations:

$$
\begin{aligned}
& \mathrm{CaCl}_{2}+3 \mathrm{CaO} \cdot \mathrm{Al}_{2} \mathrm{O}_{3} \cdot 6 \mathrm{H}_{2} \mathrm{O}+4 \mathrm{H}_{2} \mathrm{O} \\
& \longrightarrow 3 \mathrm{CaO} \cdot \mathrm{Al}_{2} \mathrm{O}_{3} \cdot \mathrm{CaCl}_{2} \cdot 10 \mathrm{H}_{2} \mathrm{O} \\
& 2 \mathrm{NaCl}+3 \mathrm{CaO} \cdot \mathrm{Al}_{2} \mathrm{O}_{3} \cdot 6 \mathrm{H}_{2} \mathrm{O}+\mathrm{Ca}(\mathrm{OH})_{2}+4 \mathrm{H}_{2} \mathrm{O} \\
& \longrightarrow 3 \mathrm{CaO} \cdot \mathrm{Al}_{2} \mathrm{O}_{3} \cdot \mathrm{CaCl}_{2} \cdot 10 \mathrm{H}_{2} \mathrm{O}+2 \mathrm{NaOH}
\end{aligned}
$$

Similarly binding of $\mathrm{SO}_{4}{ }^{2-}$ ions is as a result of formation of gypsum or ettringite as shown in the following equations:

$$
\begin{aligned}
& \mathrm{Ca}(\mathrm{OH})_{2}+\mathrm{Na}_{2} \mathrm{SO}_{4}+\mathrm{H}_{2} \mathrm{O} \\
& \longrightarrow \mathrm{CaSO}_{4} \cdot 2 \mathrm{H}_{2} \mathrm{O}+2 \mathrm{Na}(\mathrm{OH}) \\
& 6 \mathrm{Ca}^{2+}+3 \mathrm{SO}_{4}{ }^{2-}+\mathrm{Al}_{2} \mathrm{O}_{6}{ }^{6-}+32 \mathrm{H}_{2} \mathrm{O} \\
& \longrightarrow 3 \mathrm{CaO}^{6-} \mathrm{Al}_{2} \mathrm{O}_{3} \cdot 3 \mathrm{CaSO}_{4} \cdot 32 \mathrm{H}_{2} \mathrm{O}
\end{aligned}
$$

In this study, the rate of ingress was predominantly dictated by the cement type. All pozzolana cements, except those at higher replacements, gave a lower rate of ingress compared to OPC at each w/c. This can be explained by the fact that presence of pozzolana leads to a greater precipitation of cement gel products than it occurs in OPC. This blocks the pores more effectively and therefore helps to reduce permeability. The water-soluble calcium hydroxide liberated by hydrating cement may leach out of hardened concrete and leave voids for the ingress of water. Calcium hydroxide $(\mathrm{CH})$ is reduced during pozzolanic reaction, hence reducing its leaching aspect of $\mathrm{CH}$. The additional products from pozzolanic reaction, C-S-H, will close the voids, which result in more dense concrete and consequently reduce the permeability of concrete arising from a pore refining process.

As the w/c ratio increased, there was a marked rise in the sulphate and chloride ingress in all the profile depths of the test cements in the order $0.40<0.50<0.60$. Increase in the $\mathrm{w} / \mathrm{c}$ ratio, increases the pores size, hence increasing the porosity of the resultant mortar. This results in higher 


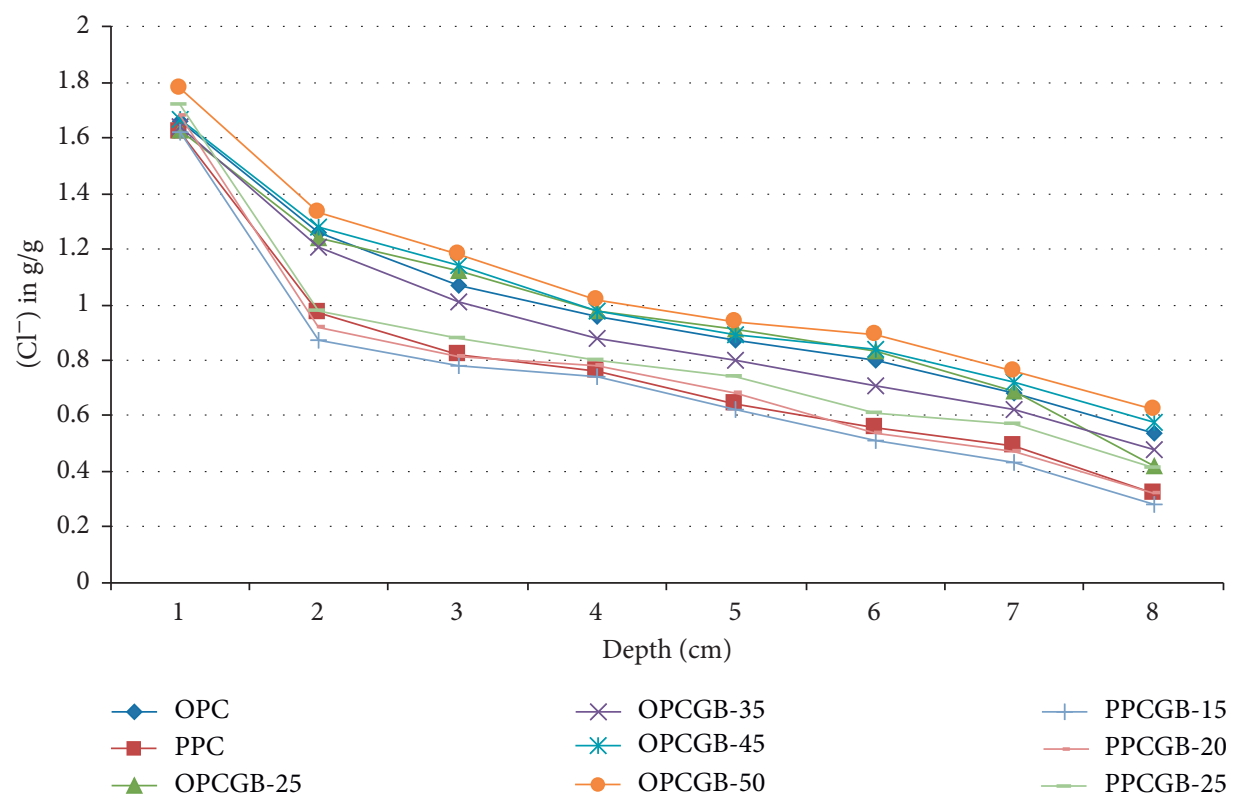

Figure 5: Chloride profile of test cements at $0.4 \mathrm{w} / \mathrm{c}$ against depth of cover.

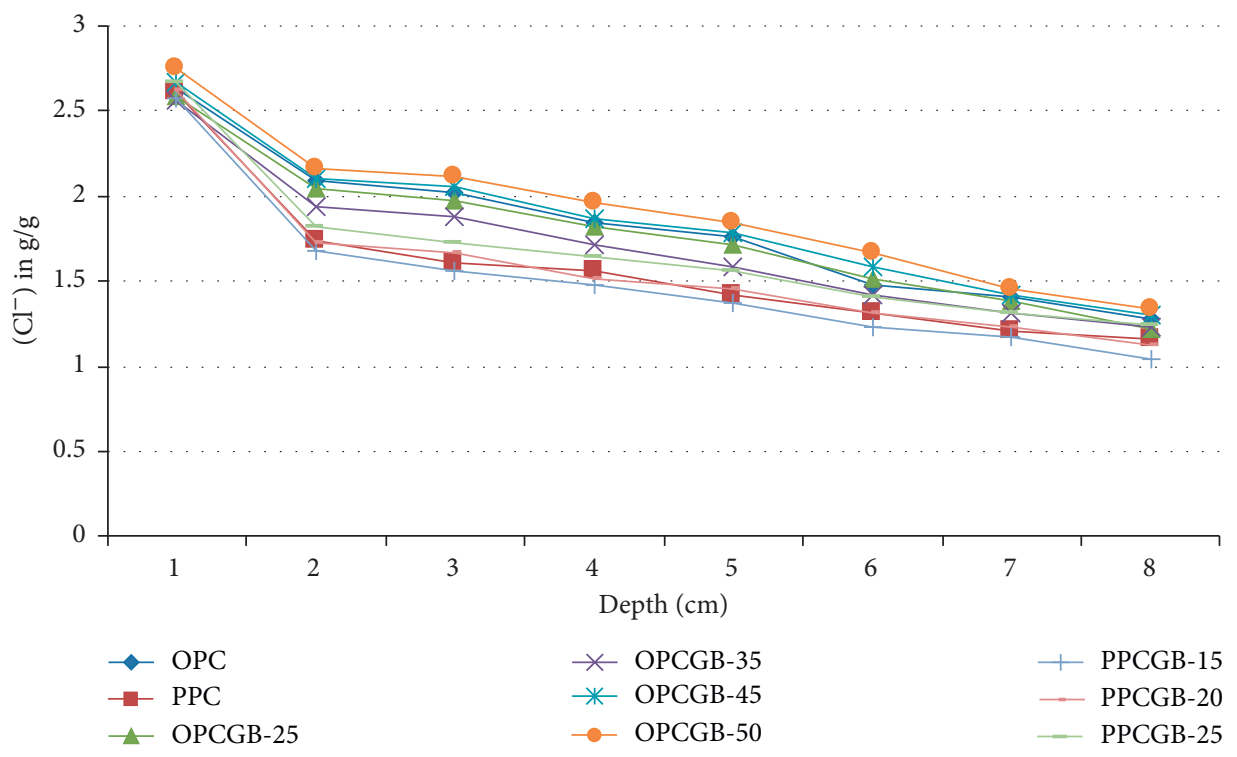

Figure 6: Chloride profile of test cements at $0.5 \mathrm{w} / \mathrm{c}$ against depth of cover.

diffusivity of sulphate and chloride into the mortar. Decreased $\mathrm{w} / \mathrm{c}$ ratio increases the resistance of concrete/mortar by lowering permeability and porosity.

Replacement of OPC beyond a certain level makes the mortar cement to be highly porous and less dense with low amount of $\mathrm{CSH}$. This makes the cement mortar to provide continuous and interlinked voids that provided pathways for ion ingress and low ion binding ability. This probably could be due to excess unreacted pozzolana grains which provide voids for the ions in solution to diffuse through easily. In this study, at beyond 35 percent replacement of OPC and 15 percent replacement of PPC, the amount of sulphate and chloride ingress in cement mortar gradually increased at all w/c. This can be attributed to the fact that the excess pozzolana only served as a filler material.

\subsection{Apparent Diffusion Coefficients for Sulphate and Chloride} Ions. The error fitting curves for determination of apparent sulphate and chloride diffusion coefficients $\left(D_{\text {app }}\right)$ for the test cements, OPCGB (0.6/50) and PPCGB (0.4/20) mortar, are presented in Figures 11 and 12, respectively. The $D_{\text {app }}$ data for each cement category is also presented in Tables 2-3. Similar error fitting curves were used for determination of the apparent diffusion coefficients for each cement category at $\mathrm{w} / \mathrm{c}=0.40, \mathrm{w} / \mathrm{c}=0.50$, and $\mathrm{w} / \mathrm{c}=0.60$. 


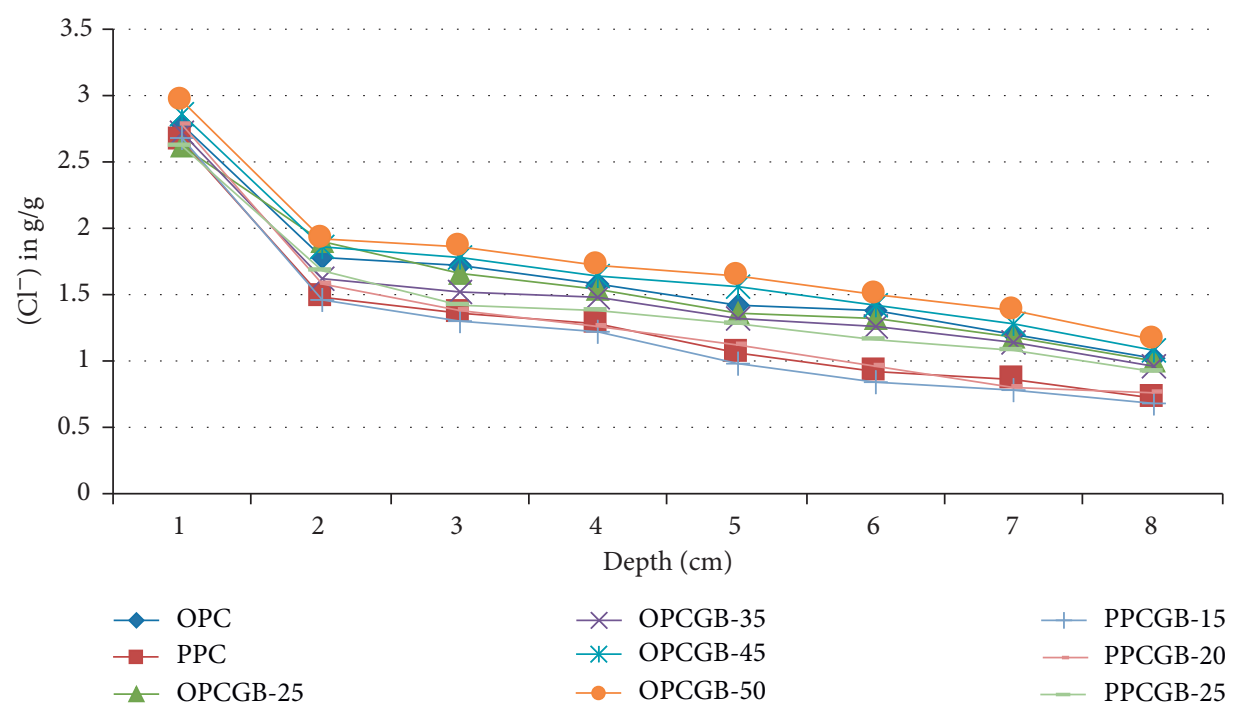

FIGURE 7: Chloride profile of test cements at $0.6 \mathrm{w} / \mathrm{c}$ against depth of cover.

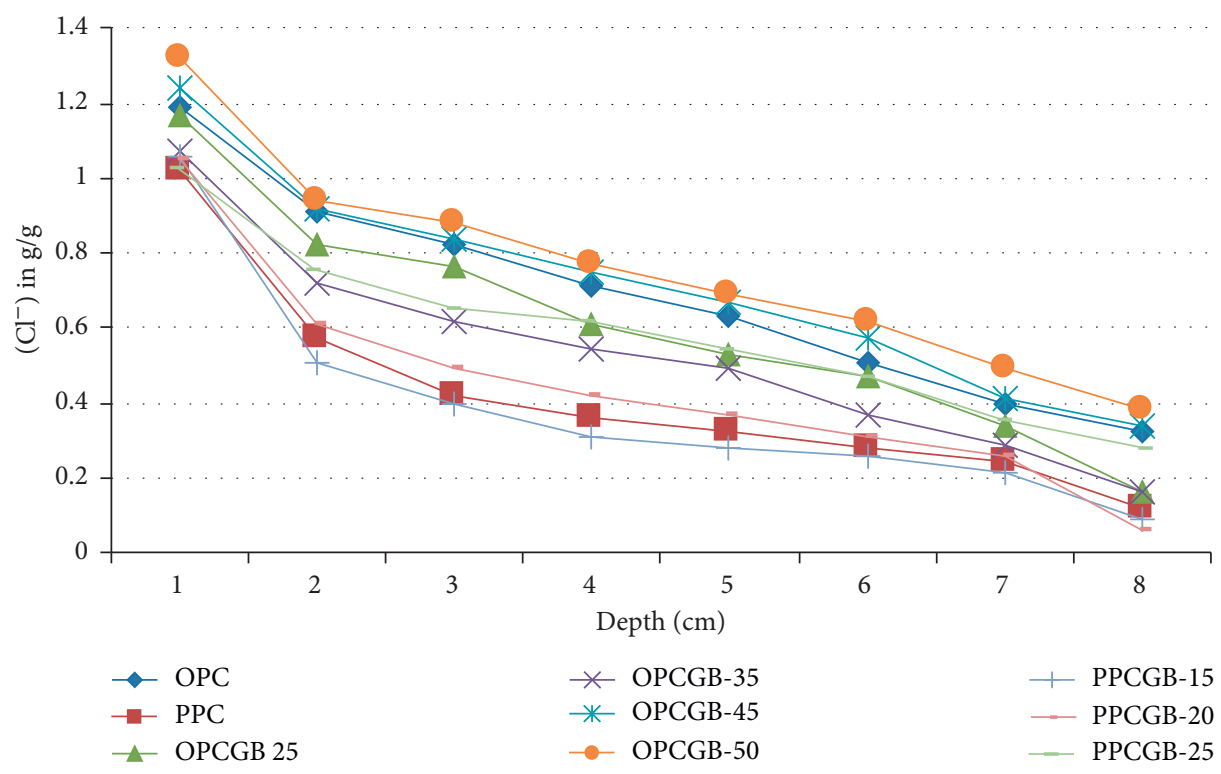

Figure 8: Sulphate profile of test cements at $0.4 \mathrm{w} / \mathrm{c}$ against depth of cover.

From Tables 2 and 3, it was observed that the blended cement (except OPCGB-50) showed lower $D_{\text {app }}$ than OPC at all w/c ratios. The low $D_{\text {app }}$ would thus be expected to mean lower ingress. This could be linked to high content of $\mathrm{Ca}(\mathrm{OH})_{2}$ in OPC which reacts with $\mathrm{SO}_{4}{ }^{2-}$ and $\mathrm{Cl}^{-}$forming expansive products (gypsum and ettringite or Friedel's salt) [10]. These cause expansion which occurs as microcracks in the mortar. Perhaps, the increased porosity prevents the formed products to act as barriers for ingress of the aggressive ions. This lowers the permeability due to pozzolanic reaction and packaging of pozzolana grains which reduces the voids. In addition, blended cement has a higher ion binding capacity than OPC. This leads to removal of the aggressive ions from the pore structure of cement mortar, giving low ingress and hence low $D_{\text {app }}$. Pozzolana in blended cement provides extra grains in hydrated cement as well as formation of secondary cementious materials which reduces the voids. This lowers porosity, decreasing the permeability of the aggressive ions into the blend cement than in OPC [10].

It was observed that the higher the w/c, the higher the $D_{\text {app }}$ across all cement categories. This could be due to the continuous and interlinked voids that provide pathways for ion ingress. High w/c affects porosity and permeability of mortars. In case of sulphate exposure, the mortar might have suffered from sulphate attack leading to formation of expansive products such as gypsum, brucite, and ettringite. This creates voids in the mortar, making it more permeable. 


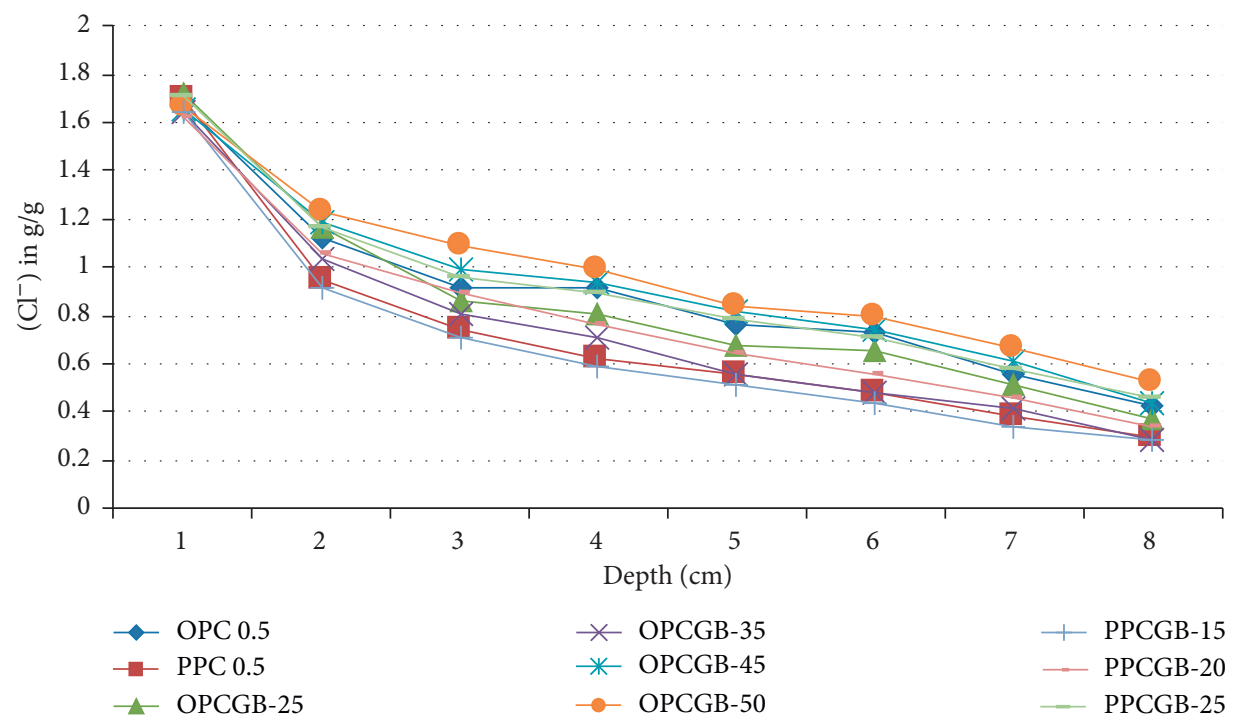

FIgURE 9: Sulphate profile of test cements at $0.5 \mathrm{w} / \mathrm{c}$ against depth of cover.

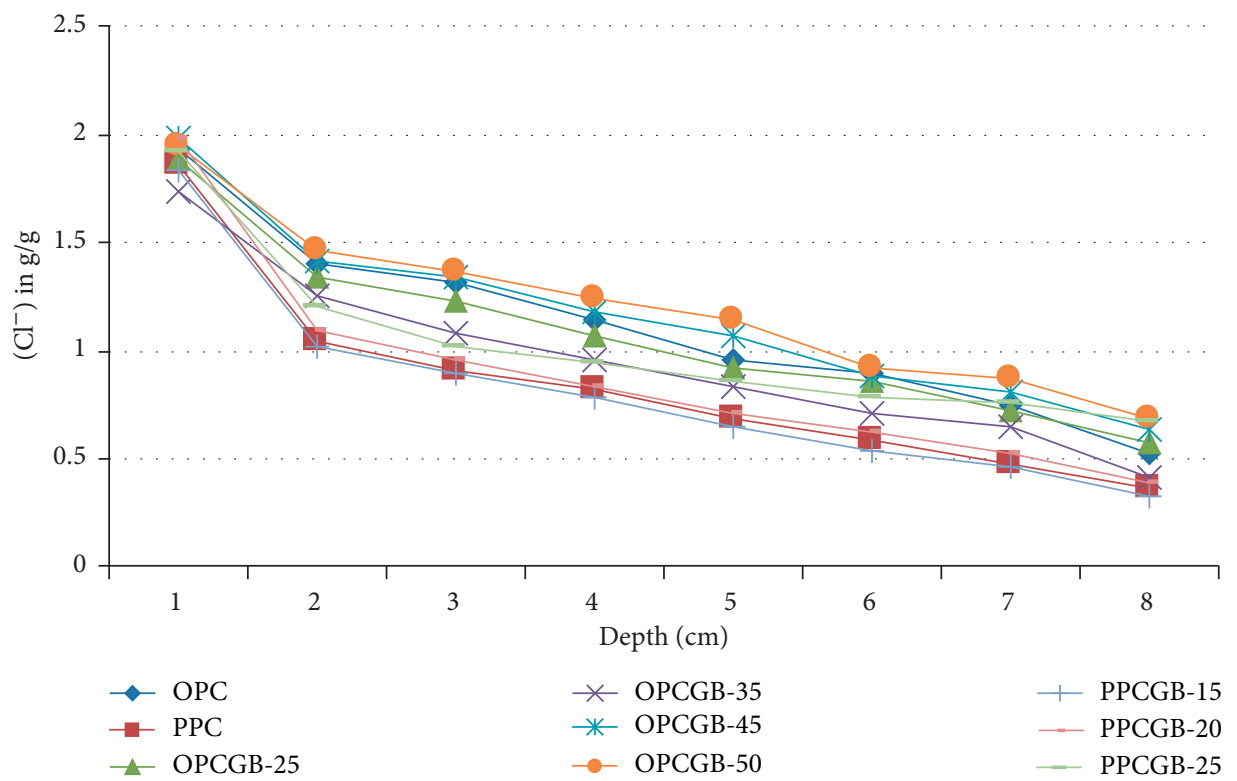

FIGURE 10: Sulphate profile of test cements at $0.6 \mathrm{w} / \mathrm{c}$ against depth of cover.

The expansive products also fill the voids which may form cracks at high w/c ratio. The cracks might have created a pathway for the ingress of sulphate ions.

From this study, $D_{\text {app }}$ values of chloride ions are higher than sulphate ions for respective test cements. The rate of diffusion of chloride ions is much higher than that of sulphate ions. This is attributed to the ionic size of chloride which is smaller than sulphate ions. In this study, the $D_{\text {app }}$ values of sulphate were in the range of $10^{-11}$ to $10^{-13} \mathrm{~m}^{2} / \mathrm{s}$ and chloride $D_{\text {app }}$ values in the range of $10^{-9}$ to $10^{-10} \mathrm{~m}^{2} / \mathrm{s}$ with OPC recording higher values than blended cement of below 45 percent replacement.
In this study, there was a marked decrease in $D_{\text {app }}$ from OPCGB-25 to OPCGB-35. This could be associated with increased ion binding and low porosity due to addition of pozzolana up to a suitable limit. This could be due to densification of hardened cement by addition of pozzolana, thus lowering porosity. Increased ion binding and low porosity are therefore the major factors that led to the decrease in $D_{\text {app }}$ from OPCGB-25 to OPCGB-35. The reduction in $\mathrm{Ca}(\mathrm{OH})_{2}$ content through pozzolanic reaction reduces a phase that is vulnerable to aggressive ion attacks. These factors make blend cement to be less vulnerable to aggressive ion attack. Also, ingress of $\mathrm{SO}_{4}{ }^{2-}$ ions initiates pozzolanic reactions, resulting 


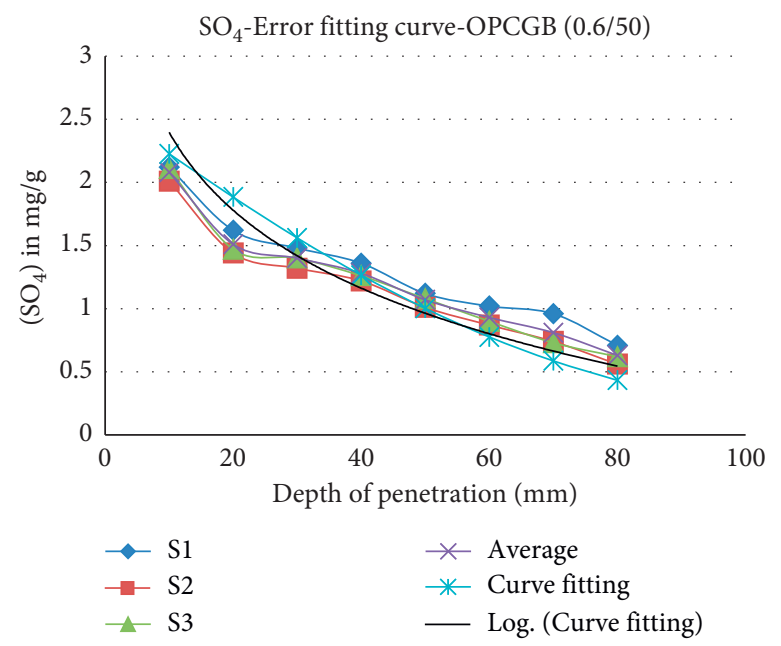

FigURE 11: Sulphate error function fitting for OPCGB (0.6/50), $D_{\text {app }}=3.68 \times 10^{-10} \mathrm{~m}^{2} / \mathrm{s}$ and Cs $=2.58 \%\left(r^{2}=0.967\right)$.

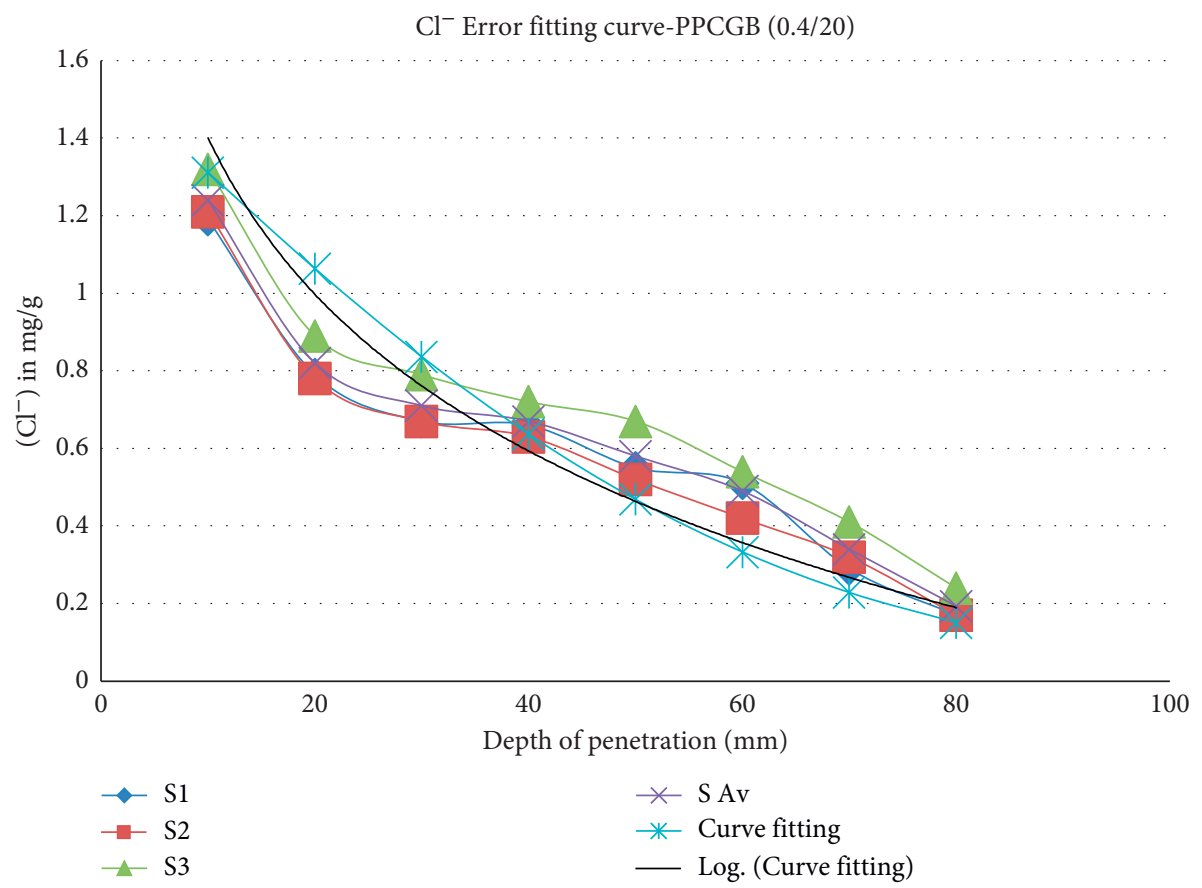

Figure 12: Chloride error function fitting for PPCGB $(0.4 / 20), D_{\text {app }}=5.06 \times 10^{-10} \mathrm{~m}^{2} / \mathrm{s}$ and Cs $=1.57 \%\left(r^{2}=0.980\right)$.

TABLE 2: Apparent diffusion coefficients of sulphate ions.

\begin{tabular}{|c|c|c|c|c|c|c|c|c|c|}
\hline \multirow{2}{*}{ Cement type } & \multicolumn{3}{|c|}{$\mathrm{w} / \mathrm{c}=0.4$} & \multicolumn{3}{|c|}{$\mathrm{w} / \mathrm{c}=0.5$} & \multicolumn{3}{|c|}{$\mathrm{w} / \mathrm{c}=0.6$} \\
\hline & $D_{\text {app }}\left(\times 10^{-10} \mathrm{~m}^{2} / \mathrm{s}\right)$ & $r^{2}$ & Cs $(\%)$ & $D_{\mathrm{app}}\left(\times 10^{-10} \mathrm{~m}^{2} / \mathrm{s}\right)$ & $r^{2}$ & Cs (\%) & $D_{\text {app }}\left(\times 10^{-10} \mathrm{~m}^{2} / \mathrm{s}\right)$ & $r^{2}$ & Cs (\%) \\
\hline OPC & 2.99 & 0.97 & 1.56 & 3.82 & 0.97 & 2.02 & 4.06 & 0.96 & 2.28 \\
\hline PPC & 2.23 & 0.99 & 1.23 & 3.19 & 0.96 & 1.38 & 3.67 & 0.96 & 1.68 \\
\hline OPCGB-25 & 2.56 & 0.97 & 1.42 & 2.91 & 0.98 & 1.99 & 3.11 & 0.97 & 2.37 \\
\hline OPCGB-35 & 2.45 & 0.97 & 1.41 & 2.69 & 0.99 & 2.13 & 2.83 & 0.98 & 2.34 \\
\hline OPCGB-45 & 2.92 & 0.97 & 1.61 & 3.16 & 0.97 & 2.13 & 3.33 & 0.97 & 2.45 \\
\hline OPCGB-50 & 3.19 & 0.96 & 1.62 & 3.38 & 0.96 & 2.03 & 3.68 & 0.97 & 2.58 \\
\hline PPCGB-15 & 1.49 & 0.99 & 1.13 & 1.98 & 0.98 & 1.68 & 2.72 & 0.97 & 1.69 \\
\hline PPCGB-20 & 1.19 & 0.99 & 1.13 & 1.60 & 0.97 & 1.62 & 2.26 & 0.97 & 1.54 \\
\hline PPCGB-25 & 2.39 & 0.97 & 1.24 & 3.59 & 0.95 & 1.62 & 3.86 & 0.94 & 1.78 \\
\hline
\end{tabular}


Table 3: Apparent diffusion coefficients of chloride ions.

\begin{tabular}{|c|c|c|c|c|c|c|c|c|c|}
\hline \multirow{2}{*}{ Binder type } & \multicolumn{3}{|c|}{$\mathrm{w} / \mathrm{c}=0.4$} & \multicolumn{3}{|c|}{$\mathrm{w} / \mathrm{c}=0.5$} & \multicolumn{3}{|c|}{$\mathrm{w} / \mathrm{c}=0.6$} \\
\hline & $D_{\text {app }}\left(\times 10^{10} \mathrm{~m}^{2} / \mathrm{s}\right)$ & $r^{2}$ & Cs $(\%)$ & $D_{\text {app }}\left(\times 10^{10} \mathrm{~m}^{2} / \mathrm{s}\right)$ & $r^{2}$ & Cs $(\%)$ & $D_{\text {app }}\left(\times 10^{10} \mathrm{~m}^{2} / \mathrm{s}\right)$ & $r^{2}$ & Cs $(\%)$ \\
\hline OPC & 9.26 & 0.96 & 2.00 & 15.5 & 0.97 & 3.07 & 16.50 & 0.96 & 3.17 \\
\hline PPC & 5.83 & 0.98 & 1.69 & 8.39 & 0.97 & 2.73 & 12.20 & 0.95 & 2.68 \\
\hline OPCGB-25 & 7.35 & 0.97 & 2.12 & 13.2 & 0.95 & 3.02 & 15.70 & 0.95 & 3.02 \\
\hline OPCGB-35 & 6.80 & 0.97 & 1.91 & 9.87 & 0.96 & 2.82 & 13.70 & 0.95 & 3.01 \\
\hline OPCGB-45 & 9.06 & 0.96 & 2.13 & 13.6 & 0.95 & 2.99 & 14.70 & 0.94 & 3.06 \\
\hline OPCGB-50 & 9.97 & 0.96 & 2.57 & 14.5 & 0.94 & 3.15 & 16.50 & 0.94 & 3.11 \\
\hline PPCGB-15 & 5.67 & 0.98 & 1.67 & 7.35 & 0.97 & 3.12 & 7.90 & 0.97 & 3.24 \\
\hline PPCGB-20 & 7.89 & 0.98 & 1.57 & 9.15 & 0.97 & 2.79 & 10.90 & 0.96 & 2.81 \\
\hline PPCGB-25 & 8.53 & 0.97 & 1.57 & 10.9 & 0.96 & 2.62 & 13.10 & 0.96 & 3.07 \\
\hline
\end{tabular}

in additional $\mathrm{CSH}$ which improves the physical properties of the resultant mortar. Such physical properties include compressive strength and density of the mortar. This in turn improves the resistance to aggressive ion attack by lowering the diffusivity and hence the ingress of the ions. There was a notable increase in apparent diffusion coefficients from OPCGB-45 to OPCGB-50 and from PPCGB-15 to PPCGB-25 at all the $\mathrm{w} / \mathrm{c}$ ratios. This could be attributed to excess unreacted pozzolana grains which provide voids for the ions in the solution to diffuse through easily.

There was no significant difference in sulphate and chloride ingress between OPCGB-35 and commercial PPC at $\mathrm{w} / \mathrm{c}=0.40, \mathrm{w} / \mathrm{c}=0.50$, and $\mathrm{w} / \mathrm{c}=0.60$. The $T$-calculated values for sulphate ingress were $0.0016,0.2168$, and 0.0191 , respectively. Also, T-calculated for chloride ingress were $0.0003,0.0003$, and 0.0058 . This may be attributed to the fact that in the preparation of commercial PPC, 25 to 35 percent of pozzolana is added to the OPC. Likewise, there was no significant difference in sulphate and chloride ingress between PPCGB-15 and commercial PPC at $\mathrm{w} / \mathrm{c}=0.40, \mathrm{w} /$ $c=0.5$, and $w / c=0.6$. The $T$-calculated values for sulphate ingress were $0.0436,0.0003$, and 0.0002 , respectively. Also, $\mathrm{T}$-calculated values for chloride ingress were 0.0064, 0.0019, and 0.0004 . The T-calculated values were far below the $\mathrm{T}$-critical value of 6.314 .

\section{Conclusion}

In view of the above results and analysis, the following conclusions were drawn:

(1) Compressive strength development increased with curing age and with decrease of w/c for all test cements. Also, the compressive strength increased up to 35 percent GB:OPC and a decrease on replacement of GB to PPC.

(2) The optimum GB : OPC was 35 percent replacement.

(3) $\mathrm{Cl}^{-}$and $\mathrm{SO}_{4}{ }^{2-}$ ion diffusivity increased with w/c for all the test cements, but diffusivity of $\mathrm{Cl}^{-}$ions was higher than that of $\mathrm{SO}_{4}{ }^{2-}$ ions. PPC, OPCGB-35, and PPCGB-15 exhibited similar performance in terms of $\mathrm{SO}_{4}{ }^{2-}$ and $\mathrm{Cl}^{-}$ingress, $D_{\text {app}}$, and strength development. The test cements, OPCGB-35 and PPCGB-15, can thus be used in similar environments as commercial PPC.

\section{Data Availability}

The data used to support the findings of this study are available from the corresponding author upon request.

\section{Conflicts of Interest}

The authors declare that they have no conflicts of interest.

\section{Acknowledgments}

The authors wish to thank the Jomo Kenyatta University of Agriculture and Technology, Ministry of Mining, Environment, Natural Resources, and Ministry of Roads for the provision of laboratory facilities used in this work.

\section{References}

[1] A. M. Neville, Properties of Concrete, Longman, Harlow, Essex, 4th and final edition, 1997.

[2] G. Boshoff, J. Duncan, and P. D. Rose, "Tannery effluent as a carbon source for biological sulphate reduction," Water Research, vol. 38, no. 11, pp. 2651-2658, 2004.

[3] C. Meyer, "Concrete as a green building material," in Proceedings of the Construction Materials Mindess Symposium, 2005, Vancouver, Canada, August 2005.

[4] N.-u. Amin, "Use of clay as a cement replacement in mortar and its chemical activation to reduce the cost and emission of greenhouse gases," Construction and Building Materials, vol. 34, pp. 381-384, 2012.

[5] G. M. Photiadis, "A study of various aspects of cement chemistry and industry relevant to global warming and the low carbon and low energy molten salt synthesis of cement compounds," in Global Warming-Causes, Impacts and Remedies, B. R. Singh, Ed., InTech, London, UK, 2015.

[6] M. J. Mwiti, T. J. Karanja, and W. J. Muthengia, "Properties of activated blended cement containing high content of calcined clay," Heliyon, vol. 4, no. 8, Article ID e00742, 2018.

[7] J. Kropp and H. K. Hilsdorf, Performance Criteria for Concrete Durability; State of the Art Report Prepared by RILEM Technical Committee TC 116-PCD, Performance of Cement as a Criterion of its Durability, E \& FN Spon, London, UK, 2010.

[8] J. M. Wachira, "Effects of chlorides on corrosion of simulated reinforced blended cement mortars," International Journal of Corrosion, vol. 2019, Article ID 2123547, 7 pages, 2019. 
[9] J. M. Wachira, J. M. Marangu, J. M. Marangu, and L. G. Murithi, "Chloride diffusivity in blended cement made from selected industrial and agrowastes," Advances in $\mathrm{Ma}$ terials Science and Engineering, vol. 2019, Article ID 2814320, 7 pages, 2019.

[10] J. M. Marangu, J. K. Thiong'o, and J. M. Wachira, "Chloride ingress in chemically activated calcined clay-based cement," Journal of Chemistry, vol. 2018, Article ID 1595230, 8 pages, 2018. 


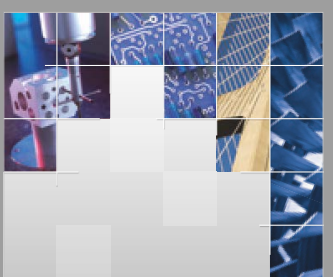

\section{Enfincering}
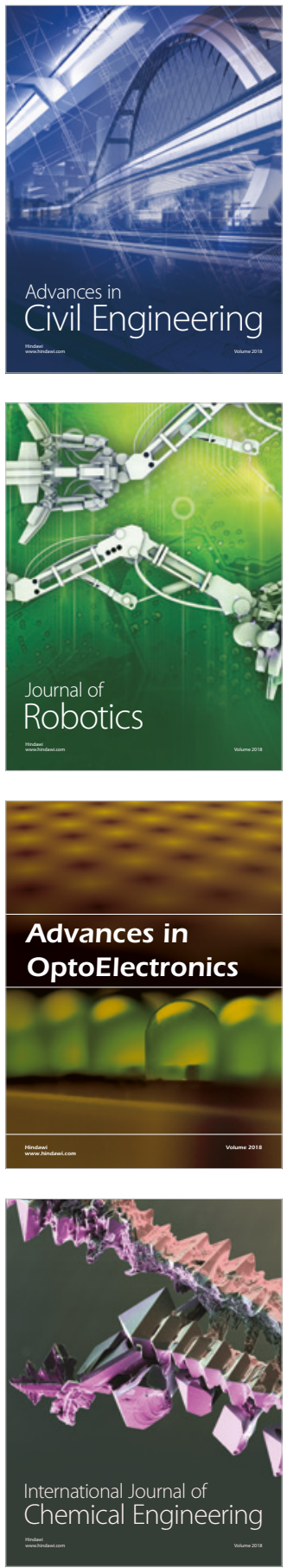

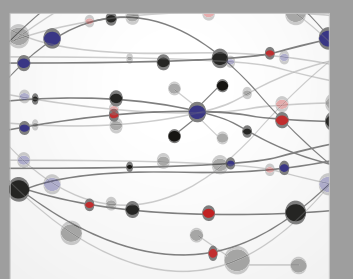

\section{Rotating \\ Machinery}

The Scientific World Journal

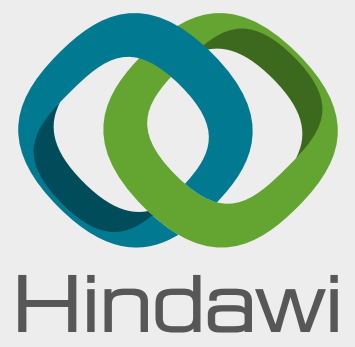

Submit your manuscripts at

www.hindawi.com
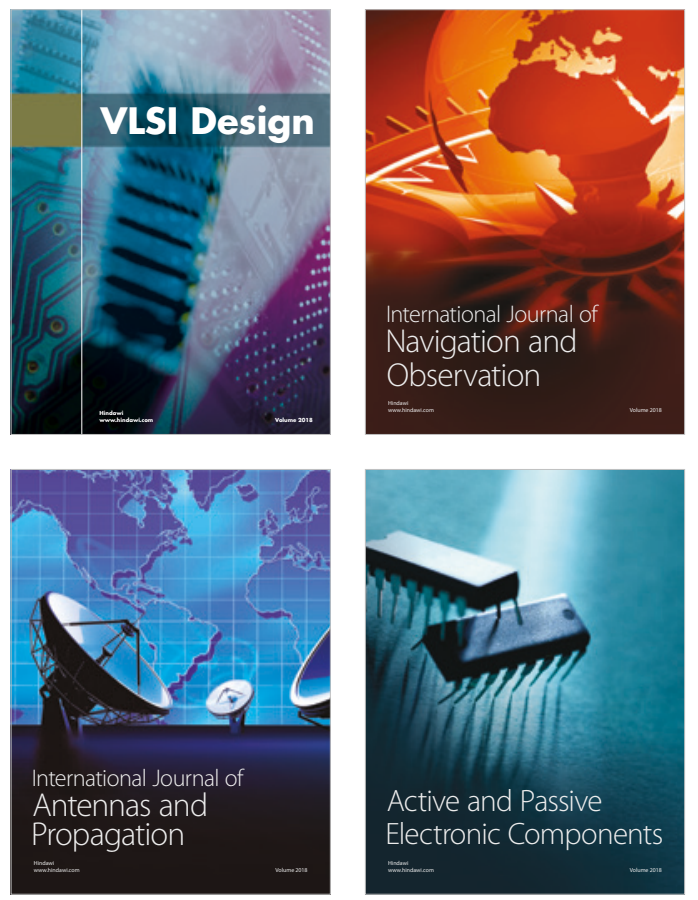
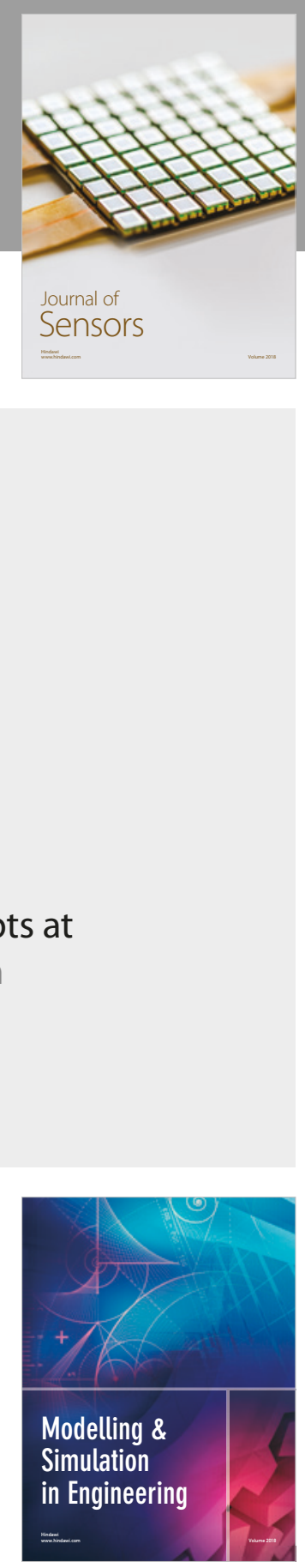

\section{Advances \\ Multimedia}
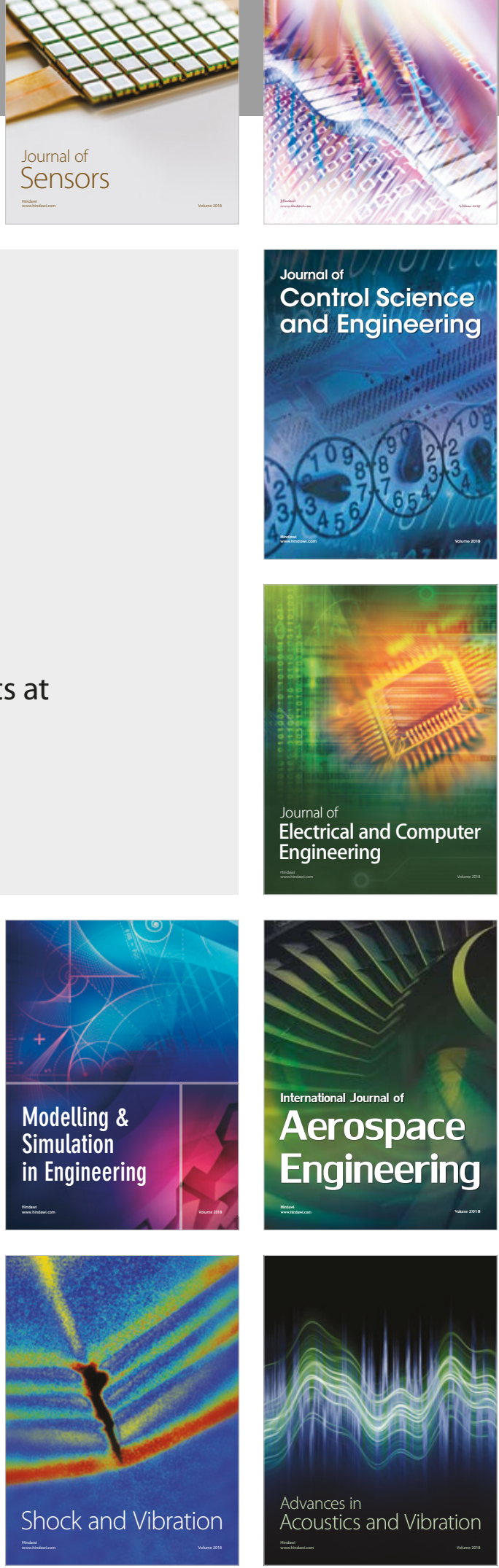